\title{
The pattern of p53 gene mutations on oral squamous cell carcinoma
}

\author{
Peter Agus \\ Department of Oral and Maxillofacial Surgery \\ Faculty of Dentistry Airlangga University \\ Surabaya - Indonesia
}

\begin{abstract}
Oral squamous cell carcinoma (OSCC) is the result of accumulation genetic lesion and caused by specific mutation in specific key regulation genes. 53 gene is key target specific regulatory genes which function as negative regulators in cell cycle control. The highest mutation rates found in human cancers and the etiology in high risk populations and the pattern of molecular pathogenesis mechanism involved in the OSCC remain unclear. The purpose of this study was to determine the presence of alteration or mutation of p53 gene and to associate these mutations histopathological status of the patients such as well differentiated and poorly differentiated in OSCC in order to elucidate the molecular pathogenesis mechanism of OSCC based on the pattern of p53 gene. Using 40 untreated well and poorly differentiated OSCC biopsy samples and 16 normal patients were analyzed for the presence of mutation in the conserved region of the p53 gene exons 5 and or 7 by PCR-SSCP mutational analysis for p53 gene showed 70\% of total samples : exon 5: 27.5\% with heterozygous mutation $81.8 \%$, exon 7: $55 \%$ with heterozygous mutation 100\%. The incidence of p53 mutation was not significantly associated with well and poorly differentiated OSCC with the exception in exon 5 of p53 gene $(p=0.013)$ using contingency coefficient. This study concludes that mutation of p53 gene especially in exon 7 may not indirectly play in the progressivity of OSCC with the exception of mutation in exon 5 of 553 which indicates the essential role in the progressivity of OSCC.
\end{abstract}

Key words: p53, exon5, exon7, mutation, OSCC, well and poorly differentiated

Correspondence: Peter Agus, c/o: Bagian Bedah Mulut dan Maksilofasial, Fakultas Kedokteran Gigi Universitas Airlangga. Jln. Mayjend. Prof. Dr. Moestopo no. 47 Surabaya 60132, Indonesia. E-mail: peter_a@indo.net.id

\section{INTRODUCTION}

Oral squamous cell carcinoma (OSCC) is the most common malignant tumor of oral cavity, it is account for $80-90 \%$ of all malignancies in oral cavity and the mortality rate remains high about 5\% in worldwide and 2,4\%-3,57\% in Indonesia. ${ }^{2}$ Up to now, The molecular pathogenesis of OSCC is still unknown and the diagnosis is only based on clinicopathological examination. Consequently, the most frequent OSCC cases are found in advanced state approximately $76,3 \%$, therefore, the management of OSCC has not shown any satisfactory outcome..$^{1,2}$

Disruption of the cell cycle as well as component regulatory genes which involved in controlling cell cycle is the main factor in the development process of all malignancies, p53 tumor suppressor gene has an important role in malignancy development process especially in early phase of cell cycle G1-S and loss of function p53 gene most common cause of OSCC. ${ }^{3}$ Futhermore, p53 gene has shown a direct in activation and has an essential role to control and to regulate cell cycle as well as to induce apoptosis. ${ }^{4,5}$ Subsequently, inactivation of p53 gene would cause the activity of p53 to be disrupted resulting in uncontrolled cell proliferation and if it continuously occurs as a result it could contribute malignancy in all cancers. The aim of this study was to determine the molecular pathogenesis of OSCC and by detecting the presence of p53 mutation in OSCC and to deserve the association of mutation with histopathological grade. The advantage of this study is expected to be able to support clinical diagnosis and histopathological of OSCC consequently the patient could be treated better.

\section{MATERIAL AND METHODS}

In this study, analytical observational comparative study by cross sectional design was used. The subjects of observation were patients who clinically diagnosed as suspected having OSCC, patients who underwent histhopatological diagnosis suffering form OSCC and normal patients who fulfilled the observation's requirement. Furthermore, patients were classified into two groups consisted of well differentiated OSCC and poorly differentiated OSCC and controlled group with normal tissue taken from impacted third molar was taken with surgery indication.

Detection of p53 gene mutation on 40 samples freshed tissue with HPA diagnostic as well and poorly differentiated OSCC and controlled group with normal tissue using PCR-SSCP with primer design p53 of exon 5 and 7 (gene bank accession number U 94788) as follows : exon $5^{1}: 5^{\text {' }}$ - TGT TCA CTT GTG GTG CCC TGA CT-3', 5'-AGC AAT CAG TGA GGA ATC AG-3' and exon 5²-CAG CCC TGT CGT CTC TCC TTC CT-3', 5'-CAG CCC TGT CGT 
CTC TCC AG-3' while exon 7': 5'-CTT GCC ACA GGT CTC CCC AA-3', 5'-AGG GGT CAG CGG CAA GA-3' and exon 7': 5'-AGG CGC ACT GGC CTC ATC TT-3', 5'-TGT GCA GGG TGG CAA GTG GC-3'. Next, DNA isolation was performed using procedure of modification DNA isolation by taking biopsy tissue OSCC and normal tissue $(1 \times 1 \times 1 \mathrm{~cm})$ with scalple and washed with PBS solution in eppendorf tubes, added with $700 \mu$ l buffer consisted of $50 \mathrm{mM}$ Tris $\mathrm{HCl}$ pH 8, $100 \mathrm{mM}$ EDTA, 100 $\mathrm{mM} \mathrm{NaCl}, 1 \% \mathrm{SDS}, 50 \mu \mathrm{l}$ of $10-20 \mathrm{mg} / \mathrm{ml}$ proteinase $-\mathrm{K}$ and incubated at $55^{\circ} \mathrm{C}$ overnight until cell suspension was achieved. The DNA was extracted from OSCC tissue and controlled tissue using $0,5 \mathrm{ml}$ phenol/CIAA and put into eppendorf shaker (eppendorf mixer 5432) for 2 hours. It was centrifuged for 5 minutes and cell suspension was put into fresh eppendorf tube and transferred into another tube added with $500 \mu \mathrm{l}$ isopropanol/ethanol until precipitated from was obtained then, the supernatant was disposed. The next step, $500 \mu \mathrm{l}$ TE buffer was added into cell suspension in eppendorf tube and incubated overnight at room temperature. Afterward, eppendorf tube was shaken manually until it was well mixed. DNA identification was done using 2\% agarose gel electrophoresis and visualized by UV light. DNA concentration test was done by spectrophotometry. ${ }^{6}$

SSCP analysis for DNA resulted from p53 gene PCR product (exon 5.7). 40 samples were divided in which every group consisting of 10 samples then, $5 \mu$ l DNA of PCR resulted from optimal product of p53 gene PCR, every group was marked with number of samples and $\mathrm{K}$ for control group. Next step, $10 \mu \mathrm{l}$ formamid was added as loading buffer, $15 \mu \mathrm{l}$ denaturation solution was achieved in eppendorf, shaken eppendorf with vertical rotater was done followed by centrifuged. Denaturation was continued in boiling water at $100^{\circ} \mathrm{C}$ for 10 minutes, and chilled using nitrogen liquid at $-80^{\circ} \mathrm{C}$ for $5-10$ minutes. Each PCR tube contained $15 \mu$ of DNA p53 gene was added with buffer loading, followed by analysis using $12 \%$ non denaturation acrylamide gel electrophoresis at room temperature for 5 hours with constant voltage $150^{\circ} \mathrm{C}$. Furthermore, silver nitrate staining was done with following procedure; fixer solution ( $7.5 \%$ acetic acid) for $30 \mathrm{~min}$ and washed $(3 \times)$ using dionized water $\left(\mathrm{dH}_{2} \mathrm{O}\right)$ for 10 minutes. Then added with $100 \mathrm{ml}$ silver nitrate solution $\left(1.5 \mathrm{~g} / \mathrm{AgNO}_{3}\right.$ and $0.056 \%$ formaldehyde) for 45 minutes and rinsed with dionized water for 15 seconds. Furthermore, image development was done with developer solution $30 \mathrm{~g} / 1 \mathrm{Na}_{2} \mathrm{CO}_{3}, 0,056 \%$ formaldehyde $2 \mathrm{mg} / \mathrm{l}$ sodium thiosulfate for $2-5 \mathrm{~min}$. Stop solution with fixer solution $7,5 \%$ acid at $\left(-4{ }^{\circ} \mathrm{C}\right)$ for 30 seconds until $5 \mathrm{~min}$. The result of SSCP analysis the product of p53 gene PCR exon 5 and 7 showed the migration pattern or single stranded conformation polymorphism (SSCP) could exhibit 2 bands in unsimilar position with 2 band of DNA resulted from controlled SSCP showed the presence of homezygote mutation. Indicating positive (+) or positive mutation (score 1), if the result was 3 bands or 4 bands of DNA p53 gene exon 5.7 unsimilar position with 2 bands of normal DNA SSCP (controlled PCR-SSCP) showed the presence of heterozygote mutation indicating positive $(+)$ or score 1 , if the result was 2 bands in p53 exon 5.7 in similar position with 2 bands in controlled PCR-SSCP indicating the absence of mutation negative (-) or score $0 .^{6}$

Cross sectional data analysis was done using SPSS program version 11. The data resulting from observation of gene mutation by PCR-SSCP method in all samples was useful to know the absence or the presence of GST p53 gene mutation (exon 5.7) and the correlation with HPA data: well and poorly differentiated OSCC. The contingency coefficient test was used for statically analysis to know the strength and the weakness of HPA correlation: well or poorly differentiated OSCC with tumor suppressor p53 gene mutation resulted from p53 gene mutation exon 5.7 in OSCC.

\section{RESULT}

The study outcome of 40 samples of tumor gene suppressor $\mathrm{p} 53$ of OSCC compared with controlled group mutation of p53 detected in exon 5: 11/40 (27.5\%) with homozygous mutation $2 / 11$ (18.2\%), heterozygous $9 / 11$ $(81.8 \%)$ while the absence of mutation $29 / 40$ (72.5\%). In p53 exon 7 showed 22/40 (55\%) mutation with heterozygous mutation $22 / 22(100 \%)$ while the absence of mutation 18/40 (45\%) shown on table 1 .

The analysis outcome of 40 patient with well differentiated HPA of OSCC, 20 mutation cases of p53 exon $5: 2 / 20 /(10 \%)$ and exon $7: 10 / 20 /(50 \%)$. The analysis outcome of 40 patient with poorly differentiated HPA of OSCC, 20 Mutation cases of p53 exon: $9 / 20(45 \%)$ and exon 7: 12/20 (60\%) the data shown below on table 2 .

Significant associated with value 0,365 and $p=0.013$ between histopathological feature of well and poorly differentiated of OSCC and mutation of p53 exon 5 of OSCC, shown on table 3.

Table 1. PCR-SSCP analysis of p53 of OSCC

\begin{tabular}{|c|c|c|c|c|c|c|c|}
\hline \multirow{2}{*}{ OSCC } & \multicolumn{7}{|c|}{ Incidence of mutations p53 (\%) } \\
\hline & & ation $(+)$ & No mutation $(-)$ & Total & Homozygote & Heterozygote & Total \\
\hline \multirow[t]{2}{*}{ p53 } & E5 & $11(27.5 \%)$ & $29(72.5 \%)$ & 40 & $2(18.2 \%)$ & $9(81.8 \%)$ & 11 \\
\hline & E7 & $22(55 \%)$ & $18(45 \%)$ & 40 & $0(0 \%)$ & $22(100 \%)$ & 22 \\
\hline
\end{tabular}


Table 2. HPA feature of p53 gene mutation of OSCC

\begin{tabular}{lcccc}
\hline \multirow{2}{*}{ HPA } & \multicolumn{2}{c}{ Mutation of p53 Exon 5 } & \multicolumn{2}{c}{ Mutation of p53 Exon 7 } \\
\cline { 2 - 5 } & Mutation (+) & No mutation $(-)$ & Mutation $(+)$ & No mutation (-) \\
\hline W Diff & 10 & 90 & 50 & 50 \\
P Diff & 45 & 55 & 60 & 40 \\
\hline
\end{tabular}

Note: $\mathrm{W}$ Diff = well differentiated, $\mathrm{P}$ Diff = poorly differentiated

Table 3. The result of statistical test of the association of histopathological feature between well and poorly differentiated p53 exon 5 of OSCC

\begin{tabular}{lllllll}
\hline & Variable & & Test & df & Value & $\mathrm{p}(\mathrm{sig})$ \\
\hline HPA & W Diff & $\begin{array}{l}\text { Mutation of p53 } \\
\text { OSCC }\end{array}$ & $\begin{array}{l}\text { Contingency } \\
\text { Coefficient }\end{array}$ & 1 & 0,365 & 0,023 \\
& P Diff & ekson5 & & & & \\
\hline
\end{tabular}

Table 4. The result of statistical test of association of well and poorly differentiated of p53 exon 7 of OSCC

\begin{tabular}{lllllll}
\hline & Variable & & Test & df & Value & $\mathrm{p}(\mathrm{sig})$ \\
\hline HPA & W.Diff & Mutation of p53 & $\begin{array}{l}\text { Contingency } \\
\text { Coefficient }\end{array}$ & 1 & 0.100 & 0.525 \\
OSCC & P.Diff & & & & & \\
\hline
\end{tabular}

The result of statistical test of the association of histophatological feature between well poorly differentiated of p53 exon 7 of OSCC, no significant association with value 0.100 and $\mathrm{p}=0.525$ between well and poorly differentiated p53 exon 7 , shown on table 4 .

\section{DISCUSSION}

The incidence of p53 mutation over 50\% was frequently found in exon 5-8 in all cancers especially exon 5 and 7 for colorectal and laryngeal carcinoma. ${ }^{7,8}$ In this study the incidence of p53 mutation in OSCC has shown 28/40 (70\%), exon 7; 22/40 (55\%) and exon 5; 11/40 (27.5\%). The result indicated that mutation of gene p53 more frequently involved in molecular control of OSCC cell cycle and it is not influenced by alteration of other tumor suppressor gene inactivation in OSCC cell cycle. Seventy percent of p53 mutation showed that p53 gene has controlling function of cell cycle and encountered $70 \%$ inactivation or loss stability of p53 function as factor of transcription gene $\mathrm{p} 21$ Walf1/Cip1, MDM2, GADD45, 14-3-3 $\alpha$ Bax and KILLER/DR5 which has an important role in controlling and regulating cell cycle, improvement of damaged DNA as well as apoptosis. In this case, p53 showed more direct role in $\mathrm{G} 1 / \mathrm{S}$ phase, comparing with gene 21 which also has direct activation in G1/S phase, however, further study is necessarily done. The dysregulation of the molecular events governing cell cycle control is emerging as a central theme of oral carcinogenesis. Regulatory pathways responding to extracellular signaling or intra cellular stress and DNA damage converge on the cell cycle apparatus. Abrogation of mitogenic and anti-mitogenic response regulatory proteins, such as the retinoblastoma tumor suppressor protein (pRB), cyclin D1, cyclin-dependent kinase (CDK) 6, and CDK inhibitors (p21(WAF1/CIP1), p27 (KIP1), and p16 (INK4a), occur frequently in human oral cancers. In this study, 30\% mutation of p53 gene was not found and probably caused by other gene mechanism such as : gene p21, pRB, p27 and oncogen cyclin D1, CDK6 involving directly in mechanism of cancer cell cycle control especially in G1-S phase of cell. ${ }^{9}$

In this study exon 7 (55\%) with heterozygous mutation $100 \%$ was found higher than exon $5(27.5 \%)$ with homozygous mutation $18,2 \%$. The result of this study also suggested that in OSCC mutation of p53 exon 7 more frequently occurred than exon 5 and mostly involved in molecular pathogenesis of OSCC. Meanwhile, p53 gene exon 5 with $81.8 \%$ heterozygous mutation and $18.2 \%$ homozygous mutation could induce uncontrolled cell proliferation, therefore p53 exon had an important role in controlling cancer cell cycle. Tumor suppressor gene p53 has the highest heterozygous mutation in exon 7 comparing with the result of study done in foreign country: $22 / 22$ (100\%), homozygous mutation $0 / 22(0 \%)$ and exon 5 with heterozygous mutation $9 / 11(81.8 \%)$ homozygous mutation $2 / 11(18.2 \%)$. The result of the study is not equivalent to the outcome of some studies done in foreign countries which suggested p53 with heterozygous mutation $65 \%$ in China, ${ }^{9}$ heterozygous mutation p53 (exon 2-9) $55 \%$ in England, ${ }^{10}$ 
and less frequent heterozygous mutation p53 in India. ${ }^{11}$ p53 gene especially exon 7 (55\%) with homozygous mutation $100 \%$ would induce loss of p53 function in which dominant mutation in one of both alelle of chromosome resulting more uncontrolled cell cycle proliferation as the cause of malignancy in OSCC, Therefore, p53 exon 7 is ideal to be molecular indicator to detect the level of malignancy especially OSCC. Meanwhile, although in p53 exon 5 less possibilities $(27.5 \%)$ of other genes mechanism was found involved in controlling cell cycle of OSCC, consequently, mutation could occur in the other region of exon 5 or in other hot spot region. Interestingly, in p53 exon 5 with high heterozygous mutation $(81.8 \%$ ) was found and it shows that p53 exon 5 also has essential role in controlling cell cycle of cancer as the cause of OSCC and could be targeted as molecular indicator to detect the level of OSCC malignancy. In this study, no significant association $(p=0.168)$ was found between well and poorly differentiation OSCC with p53 mutation of exon $7(55 \%, \mathrm{p}=0.525)$, the possibility of other gene mechanism which directly plays an essential role in the mechanism of molecular pathogenesis such as p21 gene which could directly inhibit the activation of excessive cell proliferation in cell cycle. Significant association ( $\mathrm{p}=0.0013$ ) was found in p53 gene exon 5 (27.5\%) with heterozygous mutation $81.8 \%$ and homozygous mutation $18.2 \%$ in well and poorly differentiated OSCC. This study is not equivalent to the outcome of study done in Germany for head and neck cancer and in china for breast cancer. ${ }^{12}$ So the result of this study shows that in tumor suppressor gene p53 exon 5 although the incidence of mutation is relatively small, however, it has an essential role in the progressivity of cancer, it could be shown by the presence of p53 mutation exon 5 in well differentiated OSCC (20\%) and the increase of mutation $(80 \%)$ in poorly differentiated OSCC, therefore, p53 exon 5 is ideal to be an indicator to detect the level of malignancy especially when well differentiated OSCC is found. Therefore, it could be used either as diagnosis indicator or as a molecular prognosis of OSCC.

It could be concluded that detection of p53 mutation of OSCC in oral cancer $70 \%$ of total samples was found p53 exon 7 (55\%) with heterozygous mutation $100 \%$, therefore, p53 exon 7 is ideal to be targeted indicator of molecular diagnosis and prognosis of OSCC but it is not specific for histopathological feature of well and poorly differentiated OSCC. Meanwhile, p53 exon 5 (27.5\%) has significant association in histopathological feature between well and poorly differentiated OSCC $(\mathrm{p}=0.013)$ therefore, $\mathrm{p} 53$ exon 5 is ideal to be targeted indicator of molecular diagnosis and prognosis of OSCC especially well differentiated OSCC.

In addition, it is necessary to perform a study on p53 detection using clinical feature parameter such as: age, gender, tumor location, tumor staging, TNM System and sequencing procedure is done to detect the type and location af DNA mutation so, it would be useful to increase and to confirm the outcome of this study such as: performing a study on other tumor suppressor gene which frequently involving in the mechanism of molecular pathogenesis of cell cycle such as : p21, pRB, p27, and other oncogene: cyclin D1, CdK4, E2F, MDM2 and c-myc so it would be useful to elucidate molecular pathogenesis of cancer especially OSCC.

\section{REFERENCES}

1. Neville BW, Day TA. Oral cancer and precancerous lessions. CA Cancer J Clin 2002, July-Aug 2002; 52(4):195-216.

2. Agus P. Analisis molekuler patogenesis karsinoma sel skuamosa rongga mulut berdasarkan pola mutasi gen p53 dan p16. Disertasi. Surabaya: Pascasarjana Universitas Airlangga; 2004. p. 1-7.

3. Vielba R, Bilbao J, Ispizua A, Zabalza I, Alfaro J, Rezola R, Moreno E, Elorriaga J, Alonso I, Baroja A, de la Hoz C. p53 and cyclin D1 as prognostic factors in squamous cell carcinoma of the larynx. Laryngoscope 2003 January; 113(1):167-72.

4. Kawamata H, Omotehara F, Nakashiro K, Uchida D, Shinagawa Y, Tachibana M, Imai Y, Fujimori T. Oncogenic mutation of the p53 gene derived from head and neck cancer prevents cells from undergoing apoptosis after DNA damage. Int J Oncol 2007 May; 30(5):1089-97.

5. Chang NS. The non-ankyrin C terminus of Ikappa B alpha physically interacts with p53 in vivo and dissociates in response to apoptotic stress, hypoxia, DNA damage, and transforming growth factorbeta 1-mediated growth suppression. J Biol Chem 2002 March 22; 277(12):10323-31.

6. Sambrook J, Fritsch EF, Maniatis T. Molecular cloning: a laboratory manual. $2^{\text {nd }}$ ed. New York: Cold Spring Laboratory Press; 1989. p. 6.4-6.60, 14.2-14.35.

7. Hsieh JS, Lin SR, Chang MY, Chen FM, Lu CY, Huang TJ, Huang YS, Huang CJ, Wang JY. APC, K-ras, and p53 gene mutations in colorectal cancer patients: correlation to clinicopathologic features and postoperative surveillance. Am Surg 2005 Apr; 71(4):336-43.

8. Russo A, Corsale S, Agnese V, Macaluso M, Cascio S, Bruno L, Surmacz E, Dardanoni G, Valerio MR, Vieni S, Restivo S, Fulfaro F, Tomasino RM, Gebbia N, Bazan V. TP53 mutations and S-phase fraction but not DNA-ploidy are independent prognostic indicators in laryngeal squamous cell carcinoma. J Cell Physiol 2006 January; 206(1):181-8.

9 Todd R, Hinds PW, Munger K, Rustgi AK, Opitz OG, Suliman Y, Wong DT. Cell cycle dysregulation in oral cancer. Crit Rev Oral Biol Med 2002; 13(1):51-61.

10. Bai WL, Gao H, Ren Z, Pan ZM. Detection of mutation in exon 5 and exon 8 of PTEN in laryngeal squamous cell carcinoma. Zhonghua Er Bi Yan Hou Ke Za Zhi 2004 January; 39(1):13-6.

11. Kannan S, Yokozaki H, Jayasree K, Sebastian P, Mathews A, Abraham EK, Nair MK, Tahara E. Infrequent loss of heterozygosity of the major tumour suppressor genes in Indian oral cancers. Int J Oral Maxillofac Surg 2002 August; 31(4):414-8.

12. Hong Y, Miao X, Zhang X, Ding F, Luo A, Guo Y, Tan W, Liu Z, Lin D. The role of $\mathrm{p} 53$ and MDM2 polymorphisms in the risk of esophageal squamous cell carcinoma. Cancer Res 2005 October 15; 65(20):9582-7.

13. Kumar S, Walia V, Ray M, Elble RC. p53 in breast cancer: mutation and countermeasures. Front Biosci. 2007 May 1; 12:4168-78. 